\title{
The Kodály and Rajkó Methods: Voices, Instruments, Ethnicity, and the Globalization of Hungarian Music Education in the Twentieth Century
}

\section{Lynn M. Hooker}

\begin{abstract}
Music is one of the fields in which Hungary has distinguished itself around the world, and music education is an arena in which Hungarian methods have had a profound impact. The basic principles of Hungarian music-pedagogical methods, developed by Zoltán Kodály (1882-1967) and his disciples and thus known as the Kodály method, are systematic instruction in sight-singing using "movable-do" solfège and rhythmic syllables, with the ideal of developing music literacy in all children through high-quality music, mainly classical and folk repertoire for choirs. Another type of well-known Hungarian music, so-called "Gypsy music," is specifically denied legitimacy both in Kodály's writings and those of some of his students, for two reasons: much of it is primarily instrumental instead of vocal, and it is considered "bad." Yet Romani (Gypsy) musicians from Hungary have also become famous internationally, some from quite a young age. The Rajkó Ensemble, established in 1952 as the Gypsy Orchestra of the Young Communists' League, brought Hungarian and Hungarian-Gypsy music to over a hundred countries over the years. Interviews with Rajkó members, some conducted by the author and some previously published, reveal those musicians struggling to claim the legitimacy not only of their music but of their music pedagogy, implicitly comparing the Rajkó method to the Kodály method. After a brief discussion of the Kodály method and its history, this essay gives some examples of how that method has dealt with talented Romani youth in Hungary; compares the Kodály method to methods of teaching instrumental music in Roma communities and in the Rajkó Ensemble; and considers how American ideals of multicultural education challenge some of Kodály's tenets.
\end{abstract}

Keywords: Music pedagogy in Hungary, Zoltán Kodály, Rajkó Ensemble, Romani (Gypsy) musicians

Biography: Lynn M. Hooker is Associate Professor of Hungarian Studies and Adjunct Associate Professor of Music (Musicology) and Ethnomusicology at Indiana University, where she teaches courses on Béla Bartók, Hungarian and Roma (Gypsy) history and culture, and the folk music, art music, and popular music of Central and Eastern Europe. She received her PhD in the History and Theory of Music from the University of Chicago in 2001. Her book Redefining Hungarian Music from Liszt to Bartók was published by Oxford University Press in 2013. Her current research explores the roles of Romani musicians in Hungary as artists, workers, and citizens since the nineteenth century.

(cc) $\mathrm{Br}$

ULLS D-Serle
New articles in this journal are licensed under a Creative Commons Attribution 4.0 International License.

This journal is published by the University Library System of the University of Pittsburgh as part of its D-Scribe Digital Publishing Program and is cosponsored by the University of Pittsburgh Press 
Hooker, Lynn M. “The Kodály and Rajkó Methods: Voices, Instruments, Ethnicity, and the Globalization of Hungarian Music Education in the Twentieth Century." Hungarian Cultural Studies. e-Journal of the American Hungarian Educators Association, Volume 6 (2013): http://ahea.pitt.edu DOI: 10.5195/ahea.2013.117

Music is one of the fields in which Hungary has distinguished itself around the world, on multiple levels. Works by composers Liszt, Bartók, Ligeti and Kurtág are regularly played around the world. Hungarian classical performers have become famous around the world, beginning in the early nineteenth century with virtuoso performer and composer Franz/Ferenc Liszt (1811-1886) through conductors like Hans/János Richter (1843-1913), Antal Doráti (19061988), György/Georg Solti (1912-1997), and the Fischer brothers, Ádám (b. 1949) and Iván (b. 1951); pianists Annie Fischer (1914-1995), György Cziffra (1921-1994), András Schiff (b. 1953), and Zoltán Kocsis (b. 1952), the last of these also a prominent conductor; cellist János Starker (1924-2013); and violinists from Joseph Joachim (1831-1907) through Jenő Hubay (1858-1937) and Joseph Szigeti (1892-1973) to present-day prize-winning virtuoso Barnabás Kelemen (b. 1978). Beyond individual composers and performers, Hungarian music has made an impact on the world in another sense: the style and repertoire known as "Gypsy music," a staple not only of Hungary's musical life, from the village to the capital, but also of its national image and tourist industry.

While one can find claims that Hungarians are a naturally musical people, one of the reasons for the prominence of so many Hungarians in the international music world is a robust tradition of music education found in Hungary. Since the mid-twentieth century, music education in Hungary became a point of national interest in pride, as Hungarian music teachers built a national network of schools on the pedagogical philosophy of composer and scholar Zoltán Kodály (1882-1967). The Hungarian model of music education, which has also been adopted by music pedagogues around the world, deliberately eschews Hungary's "Gypsy music," but when I conducted interviews with dozens of Gypsy musicians in Budapest during the spring of 2012, I found more connections between Kodály's than I had previously suspected. Many musicians who made their careers in Gypsy orchestras, whether in restaurants or accompanying dance ensembles, received much of their early musical training in music schools whose curriculum was defined by Kodály and his colleagues and students. Also, some musicians who were members of the Rajkó Ensemble (the Gypsy Orchestra of the Young Communists' League) compared the teaching methods used in that ensemble explicitly and positively to Kodály's music education methods, though Kodály and his students were less than complimentary about "Gypsy music" in general.

Prompted by my consultants' comments, I here offer brief histories of both the Kodály method and what they called the Rajkó method of music education, drawing on secondary and primary published sources and my interviews, and discuss what Gypsy musicians' experiences illustrates about the role ethnicity played in music educational experiences in Hungary and in the spread of Hungarian music and music education abroad.

\section{"Music Should Be for Everyone:” A Brief History of the Kodály Method of Music Education}

Composer and folk music scholar Zoltán Kodály (1882-1967) stated that he first turned his attention to elementary music education in 1925; in the late 1920s, he and his students founded the Éneklö Ifjúság ['Singing Youth'] movement to further music education among the young, mainly through youth choirs. Kodály wrote extensively for music-pedagogical purposes in the interwar period, both choral music (ranging from very simple works for novice singers to very complex ones with and without accompaniment) and prose setting out the principles of music education he advocated. Singing Youth organized several youth song festivals during the 
Hooker, Lynn M. “The Kodály and Rajkó Methods: Voices, Instruments, Ethnicity, and the Globalization of Hungarian Music Education in the Twentieth Century." Hungarian Cultural Studies. e-Journal of the American Hungarian Educators Association, Volume 6 (2013): http://ahea.pitt.edu DOI: 10.5195/ahea.2013.117

interwar period, in which ensembles performed works both from great European choral literature of the sixteenth to eighteenth centuries and new Hungarian works by Kodály and his colleagues (Pukánszky 2005, 34-35).

The phrase "Music belongs to everyone," which Kodály wrote as the preface for a volume of his writings published in 1954, became known in the imperative mode-Legyen a zene mindenkié! ['Music should be for everyone!'] — as the slogan, or perhaps the call to arms, of Kodály's educational philosophy (Kodály 2007, vol. 1, 7). He wanted everyone, not just a musical elite, to be able to participate in serious music: "It is the right of every citizen to be taught the basic elements of music, to be handed the key with which he can enter the locked world of music" (Bónis 1974, 77, quoted by Houlahan and Tacka 2008, 19). Universal music education, to take place chiefly in choirs, was his chosen tool toward accomplishing this goal. Some of the justifications he gave were cognitive and physical:

$[\ldots]$ the elements of music are precious instruments in education. Rhythm develops attention, concentration, determination and the ability to condition oneself. Melody opens up the world of emotions. Dynamic variation and tone colour sharpen our hearing. Singing, finally, is such a many-sided physical activity that its effect in physical education is immeasurable [...] (Bónis 1974, 130, quoted by Houlahan and Tacka 2008, 19).

But perhaps the most important benefits Kodály saw in singing were spiritual, as a balm against the alienating forces of modernity: "Music is nourishment, a comforting elixir. Music multiplies all that is beautiful and of value in life. [...] Our age of mechanization leads along a road ending with man himself as a machine; only the spirit of singing can save us from this fate" (Bónis 1974, 130, quoted by Houlahan and Tacka 2008, 19).

Significantly, Kodály considered instrumental music secondary to vocal music. In a 1941 article, Kodály explained his emphasis on vocal music as a matter both of socio-economics and of pedagogy:

Deeper musical cultivation is only developed where the voice was the foundation. The [musical] instrument is a thing of the few, of the privileged. The human voice, accessible to everyone, free of charge, still the most beautiful instrument, is the only possible fertile ground for a general music culture, embracing many. $\mathrm{He}$ who only knows the score together with an instrument cannot be freed in his whole life from the idea of holding the instrument at the same time-only with difficulty does he achieve free score-reading without the material (Kodály 2007, vol. 1, 117).

[Mélyebb zenei müveltség mindig cask ott fejlödött, ahol ének volt az alapja. A hangszer a kevesek, kivaltságosak dolga. Az emberi hang, a mindenkinek hozzáférhetö, ingyenes és mégis legszebb hangszer lehet cask általános, sokakra kiterjedö zenekultúra termö talaji. Aki cask hangszerrel együtt ismeri meg a kottát, egész életére nem szabadul a hangszerfogások kisérö képzetétöl-szabad, anyagtalan kottaolvasásig nehezen jut el.] 
Hooker, Lynn M. “The Kodály and Rajkó Methods: Voices, Instruments, Ethnicity, and the Globalization of Hungarian Music Education in the Twentieth Century." Hungarian Cultural Studies. e-Journal of the American Hungarian Educators Association, Volume 6 (2013): http://ahea.pitt.edu DOI: 10.5195/ahea.2013.117

Despite the popular moniker "Kodály method," Kodály himself neither invented the primary tools the method uses to bring children into music literacy nor implemented them personally in schools. Of the three main tools employed in Kodály practice, the first, tonic solfège singing (also known as the moveable do approach), dates back to the Middle Ages; the second, hand signs to indicate scale degrees, were adapted from a system originally developed by English choirmaster John Curwen in 1870; and the third, rhythm duration syllables, were adapted from those invented by Jacques Chevé in the 1800s (Choksy et al. 2001, 84-88). Kodály himself wrote a great deal of prose about his philosophy of music education, composed many pedagogical singing exercises arranged progressively, and co-edited two of the most significant early attempts at singing texts for young children published in Hungarian, Iskolai énekgyüjtemény ('School collection of songs' 1943-44, with György Kerényi) and Énekeskönyv az általános iskolák számára ('Songbook for Primary Schools' 1947-8, with Jenő Ádám) (Eősze et al. 2001). These texts, however, came to be viewed as progressing too quickly from one musical concept or skill to another; they were later superseded by other texts written by the aging Kodály's colleagues and disciples, who were more involved in choir directing and classroom teaching on a daily basis. Rather than being the primary author or implementer, Kodály was recognized as the "driving force" of the Hungarian choral movement and innovations in music education (Choksy 1999, 8).

Of course there was music instruction for children in Hungary before these publications; in fact, vocal music had been a regular part of the required primary school curriculum since the public education law of 1868, at least on paper (Kodály 2007, vol. 1, 92). However, Kodály considered the implementation of this requirement to be woefully inadequate:

In reality this meant singing by ear one hour per week in the best schools [...] The curriculum speaks of score reading as well, but one never sees anyone who has learned to read music in primary school. Since the capital has instituted specialty teaching, perhaps one or two of the more talented teachers have succeeded, but scarcely at all before the fourth grade. (Kodály 2007, vol. 1, 92-93)

[A valóságban ez heti 1 óra hallás utáni dalolást jelentett a legjobb iskolákban [...] A tanterv ugyan kottaismeretröl is szól, de még senki sem látott embert, aki az elemiben megtanult volna kottát olvasni. Mióta a fóváros bevezette a szaktanítást, talán sikerül egy-két ügyesebb tanítónak, de a negyedik osztályig alig.]

Many schools had substantial choirs in later grades, and Kodály appeared to bless their performances regularly throughout the 1930s. However proficient, though, choirs in upper grades did not satisfy Kodály's urging (like that of many music educationists) for regular quality music instruction as early as possible for as many students as possible.

\section{Music Education in Post-war Hungary and the Spread of the "Kodály Method"}

At the end of World War II, music education was one of the many things in Hungarian society to be reorganized. Minutes from a February 1945 meeting of the music pedagogy committee of the new Magyar Pedagógusok Szabad Szakszervezete ['Free Union of Hungarian Educators'], with Kodály student Pál Kadosa at its head, identified some of the same problems in school music teaching that Kodály had, in more detail: "In the past, teachers who do not 
Hooker, Lynn M. “The Kodály and Rajkó Methods: Voices, Instruments, Ethnicity, and the Globalization of Hungarian Music Education in the Twentieth Century." Hungarian Cultural Studies. e-Journal of the American Hungarian Educators Association, Volume 6 (2013): http://ahea.pitt.edu DOI: 10.5195/ahea.2013.117

understand music, teachers of theology, physical education teachers, etc., were compelled to oversee music teaching-badly, of course" [A múltban zenéhez nem értö tanitók, hittan, tornatanárok stb. kényszerültek ellátni a zenetanítást, természetesen rosszul]. Since, in the group's estimation, "the proper music education of the broad masses falls on the primary school" [a széles tömegek helyes zenei nevelése az elemi iskolában döl el], it recommended the institution of teacher preparation courses and a revision of the curriculum based on "the most progressive and most developed methods of vocal pedagogy" [a leghaladóbb és legfejlettebb énekpedagógiai módszerekkel] (Berlász \& Tallián 1984, 31). It is clear both in this emphasis on singing and in other documents from successive months and years that those methods and the philosophy behind them were primarily Kodály's. A report from September 1945 made that link clear, through implied references to Kodály's folk music writings and explicit references to his pedagogical publications:

[...] the organic development of Hungarian musical life leads through vocal instruction in school, because the ancient Hungarian musical tradition is totally oral, sung music. The ancient layer of our vocal music that has survived in peasant songs is completely different from the musical materials of the neighboring peoples, thus it is characteristic Hungarian cultural material at its root (pentatonic style). Hungarian music also substantively diverges from the music of the neighboring peoples in that it is not instrumental but vocal in origin. As a consequence of this, our system of vocal pedagogy cannot be identical with the instrumental-type system of music education of the Germanic and Slav peoples. Our older singing texts did not recognize this fundamental thing [...] and thus they have become obsolete. Our newer singing texts based on peasant songs (Kerényi-Rajeczy: Singing ABC, Kodály: School Song Collection, KodályÁdám: So-Mi) have already eliminated this discrepancy (Berlász \& Tallián 1984, $71)$.

[ [...] a magyar zenei élet szerves kifejlesztése az iskolai énekoktatáson keresztül vezet, mert az ösi magyar zenei hagyomány teljesen oralis, énekes zene. A paraszt-dalokban fennmaradt énekes zenénk ösi rétege teljesen különbözik a környezö népek zenei anyagtól, tehát sajátfejlödésü, gyökeresen magyar kultúrtermék (pentaton-stílus). A magyar zeneiség abban is lényegesen elüt a környezö népek zeneiségétöl, hogy nem hangszeres, hanem énekes eredetü. Ebböl következöleg az énekoktatásunk rendszere nem lehet azonos a germán és szláv népek hangszeres jellegü zeneoktatásának rendszerével. Ezt az alapvetö dolgot nem ismerték fel régebbi énekeskönyveink [...] s ezért meghaladottak. A paraszdalokon alapuló újabb iskolai énekeskönyveink (Kerényi-Rajeczy: Énekes ÁBÉCÉ, Kodály: Iskolai dalgyüjtemény [sic], Kodály-Ádám: Szó-Mi) ezt az ellentmondást már kiküszöbölték.]

Kodály was not unproblematic for the Communist regime, either symbolically or personally. His emphasis on the ancient Hungarian past (endorsed in the above quotation) ran counter to the regime's official anti-nationalism, he had composed a substantial amount of religious music, and his high-art compositions carried the taint of the bourgeoisie. In 1949, a year in which the Hungarian Communists were consolidating power-a process that notoriously 
Hooker, Lynn M. “The Kodály and Rajkó Methods: Voices, Instruments, Ethnicity, and the Globalization of Hungarian Music Education in the Twentieth Century." Hungarian Cultural Studies. e-Journal of the American Hungarian Educators Association, Volume 6 (2013): http://ahea.pitt.edu DOI: 10.5195/ahea.2013.117

included the show trial and execution of László Rajk-Kodály was removed from the Presidium of the Hungarian Academy of Sciences (Beckles Willson 28). But Kodály's stature internationally and domestically, among both Communists and non-Communists, made him all but indispensable. Denying him a place in the Hungarian music scene "was going to create more problems than [his] banishment would solve. [...] Kodály, meanwhile, publicly identified his own goals with those of Soviet Russia" (Beckles Willson 2007, 30-31). His emphasis on ancient Hungarian folksong as an aspect of language, not of a now-obsolete peasant culture, had begun long before, but as Rachel Beckles Willson put it:

Kodály's belief that music was essentially of the same quality as language (and thus, in the new Stalinist linguistics, no longer part of the cultural superstructure) meant that he could feel supported by Stalin in his argument that certain melodies remained unchanged over 1500 years (Beckles Willson 2007, 36-37).

Kodály's education agenda was likely the arena in which he found the most common ground with the Communists. His slogan Legyen a zene mindenkié was completely noncontroversial. The institutions most responsible for putting this exhortation into action were the music primary schools, in which children studied music on a daily basis, mostly choral singing, alongside the regular curriculum. A single class organized on this model opened on an experimental basis, with Kodály's support, in Kecskemét, Kodály's birthplace, in 1950 under the leadership of Márta Nemesszeghy. The results were considered so positive that the program grew rapidly; music schools were gradually opened across the country, with the aim of "mak[ing] average musical education available to the broad mass of society, thereby raising its standard, and [...] apply[ing] the training power of music in the teaching of science, classics and aesthetic subjects, in other words, to master the normal curriculum better and more easily by applying abilities and skills developed in the study of music" (Friss 1969, 134). By 1969, there were an astonishing 86 state music schools in cities and towns across Hungary, with 74 branch schools in villages; over 3,000 music teachers served 65,000 children at primary institutions for music. The foundation of the Hungarian music curriculum - whether at these schools or at culture houses and Music Teachers' Cooperatives (where children could study who had been turned away at the music primary schools for lack of space)—was the same everywhere: choral singing, solfège ('sight-singing'), and music theory. Students were generally expected to complete a preparatory year of study before beginning study on an instrument (Irsai et al. 1969, 172-175).

Word of the effectiveness of the Hungarian system of music education began to spread in the late 1950s and accelerated rapidly in the 1960s. Reports on the pedagogical techniques and the institutions used in Hungary were presented at meetings of the International Society for Music Education (ISME) in 1958 in Vienna and in 1963 in Tokyo. The 1964 conference of ISME was held in Budapest; Kodály gave an address and was declared honorary president of the organization. By the end of the 1960s educators in Canada, Chile, Czechoslovakia, Estonia, France, Germany, Japan, Peru, Russia, the United Kingdom, and the United States had begun using and adapting the Hungarian method in their home countries; since then it has also spread beyond to the remaining populated continents, under the label "the Kodály Method." In 1973 at Holy Names College in Oakland, California, the first international symposium devoted to Kodály was held, an event that shortly led to the founding of the International Kodály Society and the Organization of American Kodály Educators (Choksy 1999, 4-7). In his waning years, on the combined strength of his compositional output, his scholarly achievements, and especially the 
Hooker, Lynn M. “The Kodály and Rajkó Methods: Voices, Instruments, Ethnicity, and the Globalization of Hungarian Music Education in the Twentieth Century." Hungarian Cultural Studies. e-Journal of the American Hungarian Educators Association, Volume 6 (2013): http://ahea.pitt.edu DOI: 10.5195/ahea.2013.117

impact of his pedagogical philosophy, Kodály basked in the glow of recognition abroad as well as at home: he had bestowed on him honorary degrees from Oxford, Humboldt, and Toronto Universities; invitations to conduct in Great Britain, the Soviet Union, and the United States; three Kossuth Prizes, an honor that came with a monetary award worth more than three times the average Hungarian salary; and the title "Eminent Artist of the Hungarian People's Republic" (Houlahan and Tacka 2008, 18; Haraszti 1988, 62 on the value of the Kossuth Prize).

In Hungary, though Kodály was ever-present in music pedagogy, the label "Kodály Method" was not used. Not only were there numerous teachers involved in the development and implementation of music pedagogical methods, many with much more daily investment in the classroom than Kodály had, but the use of an individual name for such a systemic development ran counter to the state's philosophy of collective rather than personal glory. So "it remained for foreigners visiting Hungary to give Kodály's name to what they saw" (Choksy 1999, 8). Whatever the label for the pedagogical method, though, Kodály's grandfatherly role overseeing events at home and abroad amplified his popularity; this benevolent image has continued to have a positive effect since his death.

\section{What Music Should Be for Everyone?}

Of course when Kodály proclaimed that "Music should be for everyone," he was not talking about all music. He wanted everyone to learn to make and appreciate good music, and by "good," he meant something quite specific: either art (classical) music or folk music. Classical music, in the form of masterworks produced by "significant" (mostly European, mostly male) composers, was at the center because it defined (and continues to define to a great degree) what it meant to be musically educated, not only in Hungary but elsewhere. Folk music was important for three main reasons: pedagogical, aesthetic, and national. Pedagogically, Kodály and his disciples believed that pentatonic Hungarian folksongs (constituting what is considered the oldest layer of Hungarian music culture) were "what is demanded by a rational pedagogical sequence" (Bónis 1974, 161); because such melodies lack semitones (half-steps), they are easier for beginners to sing in tune. Aesthetically, they argued that folk music was "music of the best kind ... equal to Bach's fugues or Beethoven's sonatas" (Járdányi 1969, 22), and that "the pure soul of the child" must have only the best (Bónis 1974, 141). But perhaps the most important reason to use Hungarian folk music in Hungarian schools was to foster children's "musical mother-tongue," something Kodály considered essential to creating a strong fundamental national identity, as he argued that no one could be truly bilingual or bimusical:

[T] he soul of the child should be nursed on the mother's milk of the ancient Magyar musical phenomenon... For the time being only that. In the same way as a child should not be allowed to learn any other language apart from his mothertongue until he has consciously mastered this latter, that is to say, not before the age of ten. Finally [in the end], a multilingual child will not know any language really well. ... The road from Hungarian music to the understanding of international music is easy, but in the opposite direction the road is difficult, or non-existent. (Bónis 1974, 153-154) 
Hooker, Lynn M. “The Kodály and Rajkó Methods: Voices, Instruments, Ethnicity, and the Globalization of Hungarian Music Education in the Twentieth Century." Hungarian Cultural Studies. e-Journal of the American Hungarian Educators Association, Volume 6 (2013): http://ahea.pitt.edu DOI: 10.5195/ahea.2013.117

Kodály's writings not only argue for the use of "good" music but also against the use of "bad" music, as in this statement from 1941: "if we plant anything bad [in the child], we poison his soul for life" (Bónis 1974, 141). The types of "bad" music that folk music was enlisted to combat were popular music, both from abroad - German children's songs used in translation, "light music" (particularly operetta), jazz, and "mechanical music" (recordings) in general — and popular genres from Hungary, mostly performed by Romani (Gypsy) musicians. Both Kodály and his followers considered "the 'half-art' of gipsy music" (Járdányi 1969, 20) a problem in the development of Hungarian music culture: the genuine article, ancient peasant folksong, was not well known outside isolated villages, indeed peasant culture was often looked down upon among the more educated urban population in favor either of imported (especially German) music or pseudo-folksong "filtered through the gipsy bands" (Járdányi 1969, 21). This type of "distorted" Hungarian material was considered even worse than foreign music, as it was liable to make a child "loathe the hackneyed outward trappings of the superficial Hungarian character before he comes to know the genuine one" (Bónis 1974, 145). "To reach a written, up-to-date culture," stated Kodály, "the outdated type of musician - half-gipsy and half-illiterate-must be eliminated most urgently" (Bónis 1974, 195). Kodály, like his colleague Bartók and like many after them, repeated this rejection as a matter of scientific fact, but among Roma musicians it is understandably not heard that way. Many among those I have interviewed protested strenuously that Gypsy music is not kitsch, it is Hungarian, and is legitimate.

Like the issue of "good" versus "bad" music, the idea that vocal music is more pedagogically significant than instrumental music is not as self-evident as Kodály sometimes asserted it to be. On the one hand, instrumental musicians have claimed "singing" as the ideal goal for instrumental tone for generations, a fact that Kodály emphasized in a 1953 commencement address at the Academy of Music with historical examples going back to the early nineteenth century. One of those examples, which he also used elsewhere, was the great Italian conductor Arturo Toscanini:

I heard the finest singing in the world by the world's worst voice $[\ldots]$ when at rehearsal [Toscanini] demonstrated a phrase in his blunt, hoarse voice for his players and singers. And this is why they could sing so beautifully under his baton. His most frequent comment to the orchestra was "Cantare! Cantare!" (Bónis 1974, 193)

Music educators around the world have shown how powerful teaching singing can be in developing musical literacy and proficiency. Still, it is worth considering how the principle of the superiority of vocal over instrumental music was applied in determining the musical potential of children. Places in Hungary's music primary schools were in high demand from the beginning, and given the curriculum, the selection criteria relied heavily on singing ability, including not only "a song of the child's own choosing" and "singing back simple sections or turns of melody, transposing them into another key, [...] etc.," but also "medical examination of the vocal chords" (Friss 1969, 135). But just as the example of Toscanini illustrates that not all excellent adult musicians can sing well or at all, it is equally valid that a child's physical ability to produce sound with the throat does not represent the entirety of their musical potential.

Possible casualties of the Kodály method's heavy emphasis on vocal over instrumental music were children from musical, but not necessarily singing, families - especially Roma (Gypsy) children. To be sure, overall school preparation and educational achievement among 
Hooker, Lynn M. “The Kodály and Rajkó Methods: Voices, Instruments, Ethnicity, and the Globalization of Hungarian Music Education in the Twentieth Century." Hungarian Cultural Studies. e-Journal of the American Hungarian Educators Association, Volume 6 (2013): http://ahea.pitt.edu DOI: 10.5195/ahea.2013.117

Hungary's Roma population has a difficult history. School attendance among Roma children in Hungary was only 50 percent in 1930, when 92 percent of non-Roma children in Hungary attended school. Though 87 percent of Roma children reaching school age between 1953 and 1958 attended school throughout Hungary, only 27 percent completed the eight grades of primary school, many of those being passed through without achieving true literacy. Roma children's school attendance and achievement was greater in Budapest and its environs, but it remained behind that of the majority (Kemény and Janky 2205, 146-151); in the present day, as well, overall educational achievement and school preparation among Hungary's Roma population remains well behind that among non-Roma, and Roma children are frequently shunted into schools with lower expectations across Europe (Messing et al. 2010). Music is one area in which Roma children are often expected to have some "innate" talent (see Gelbart 2010, 86 ), but that talent may be devalued as being generally applicable only to less worthwhile music - not only instrumental over vocal, but Gypsy music over "good" music. Statistics about the number of Roma children enrolled in Hungary's music primary schools, past and present, are unavailable, though certainly several of my interviewees did attend such schools; still, in 2012, renowned Hungarian-Roma guitarist Ferenc Snétberger, in an interview about a summer music program established specifically to identify and develop musical talents among disadvantaged, primarily Roma youth, emphasized the need for teachers who either are Roma themselves or who "know the Roma well," because "there are children in whom a teacher with normal training does not recognize what treasures these children bring from home, or that they are born with" (Makki 2012).

The prevailing understanding of what musical aptitude meant, defined according to Kodály's principles, thus could work against talented Roma youth. A vivid illustration of this problem came up in an interview I conducted with Sándor Déki Lakatos (b. 1945), scion of a long-lived dynasty of Gypsy musicians from Western Hungary and son of Sándor Lakatos (1925-1994), one of the great Gypsy violinists and bandleaders of the twentieth century. As an adult Sándor Déki Lakatos developed into a virtuoso violinist and prominent bandleader in his own right, but, he related, that future seemed very much in doubt when, at the age of six or seven (that is, around 1952 or 1953), his father brought him to one of Budapest's state-run music primary schools - still very new institutions - to audition:

And I had to go into a room, at the piano there was a lady and she said, my little boy, sing what you hear. And she struck three tones. And I could never sing in my whole life. I sang so that she just looked. Again she struck three tones, says, sing them. I couldn't sing them, but I know what notes I heard. [...] But she didn't ask that. Just that I should sing. And she said, say, my little boy, tell your parents that you are completely unfit for a musical career. And I came out. And my father says, well, what is it? The teacher lady said that I'm unfit. Yes? Did you tell her you have almost perfect pitch? Well, I said, but she didn't ask [the pitches]. But why? She said I should sing. And you told her you don't want to be a singer, but a violinist? I say she didn't ask that either. So my father knocked on the door, we went back into the room, and then he said, please don't be annoyed, he says, my son has almost perfect pitch but he cannot sing. The woman says, if he cannot sing, then he is not fit for a musical career. And then Dad went over to the piano and struck three notes, and don't be annoyed Madame Teacher, could you please tell me what notes I played? No, I can only sing them. Ah, then I would not leave 
Hooker, Lynn M. “The Kodály and Rajkó Methods: Voices, Instruments, Ethnicity, and the Globalization of Hungarian Music Education in the Twentieth Century." Hungarian Cultural Studies. e-Journal of the American Hungarian Educators Association, Volume 6 (2013): http://ahea.pitt.edu DOI: 10.5195/ahea.2013.117

my son here. He says, what did you hear, my son? And I told him what I heard. [And my father said] I surely would not leave my child here [to study] with you. And then they signed me up at [a private] music school [...] (Interview with author in Szentendre, Hungary, March 8, 2012)

[És be kellett mennem egy szobába, zongora egy hölgy és azt mondta, kisfiam, amit hallasz hangot azt énekeljed. És leütött három hangot, és soha életemben nem tudtam énekelni. Olyanokat énekeltem, hogy csak nézett. Megint leütött három hangot, azt mondja, énekeld el. Nem tudtam elénekelni, de tudtam, hogy milyen hangokat hallok. ... de nem azt kérdezte. Azt, hogy énekeljek. És mondta, hogy mond meg kisfiam a szüleidnek, hogy zenei pályára teljesen alkalmatlan vagy. És én jöttem ki. És apán azt mondja, na, mi van? Azt mondta a tanár néni, hogy alkalmatlan vagyok. Igen? Mondtad, hogy majdnem abszolút hallásod van? Hát, mondom, azt nem kérdezte. Hát miért? Az mondta, hogy énekeljek. És mondtad, hogy nem énekes akarsz lenni, hanem hegedüs? Mondom, hát azt se kérdezte. Úgyhogy apám bekopogott, visszamentünk a terembe, és akkor mondta, ne haragudjon, azt mondja, a fiamnak majdnem abszolút hallása van, de nem tud énekelni. Azt mondja a nö, ha nem tud énekelni, akkor zenei pályára alkalmatlan. S akkor apu odament a zongorához és leütött három hangot, és ne haragudjon tanárnö, meg tetszik tudni mondani, hogy milyen hangokat játszottam? Nem, csak elénekelni tudom. Ja, akkor nem is hagynám itt a fiamat. Azt mondja, mit hallottál fiam? És én mondtam, hogy mit hallottam. Nem is hagynám itt magánál a gyerekemet. És akkor [magán] zeneiskolába irattak be...]

That the child of Sándor Lakatos, one of the country's best-known musicians, was dismissed out of hand by this teacher may be one indication of how little importance some of Hungary's state music schools saw in the musical potential of Roma children, even those whose young lives were saturated in music. In Déki Lakatos' case, he had already begun studying the violin at home and developed a refined sense of pitch, but he could not reproduce that knowledge vocally, only instrumentally or intellectually (by naming pitches). Certainly many Roma had experience singing magyar nóták ['Hungarian songs'] in the home, and perhaps in an audition could sing such songs more easily than isolated pitches, but that repertoire was devalued as "the 'half-art' of gipsy music" (Járdányi 1969, 20). Moreover, different communities often have different native aesthetics for vocal quality, and according to documentation from the early 1990s provided by Barbara Rose Lange, many ethnic Hungarians considered Roma singing to be "bellowing" (1997, 10). If a parent pushed, those children rejected by the state music primary school could pursue a musical education through a private school; but not only would such a private school cost more than the state music primary school, but music lessons through a private institution were seen as a poor second choice to the music primary school. Although Hungarian music education rhetoric emphasized the role of music primary schools in "educat[ing] a future generation of music-loving concert-goers, and train[ing] groups of children to become [...] amateurs of good taste and understanding," the other purpose of these schools was (and still is) to "provide for the selection, adequate preparation and training of pupils suitable for a musical career"; the students "who, having finished the lower grades at the ages of thirteen or fourteen, decide to choose music as a profession, sit for the entrance examination to a conservatoire" [music secondary school], which then would feed into Budapest's Academy of Music (Irsai et al. 
Hooker, Lynn M. “The Kodály and Rajkó Methods: Voices, Instruments, Ethnicity, and the Globalization of Hungarian Music Education in the Twentieth Century." Hungarian Cultural Studies. e-Journal of the American Hungarian Educators Association, Volume 6 (2013): http://ahea.pitt.edu DOI: 10.5195/ahea.2013.117

1969, 173). And as Déki Lakatos' experience indicated, a child who, for whatever reason, was not admitted into the music primary school thus was considered off the track toward a music career already at a very young age.

\section{The Education of Gypsy Musicians: From Community-Based Teaching to the Rajkó Orchestra}

But of course the kind of music career to which this track guided pupils was a komoly ['serious'], that is classical, music career. Those children aiming for careers as making "Gypsy music," usually from families with a history in the business, traditionally received their music education outside this institutional framework, either instead of, or as a complement to, studies in institutions of formal music education. This family — and community — based music education may begin in a child's infancy, when some parents place a violin bow into the child's hand, as one such parent related:

$[\ldots]$ if he takes hold of the bow from above, as he should [...] then he has a sensitivity for it. If he only grabs it like a stick, then he won't be a good musician. The parents for centuries put a lot of time and energy into observing where the child's talent lies. From the age of three the father teaches him, tries out the various instruments with him. Then, if it turns out that the child likes something, when he is six or seven they seek out a good teacher from among their circle of friends or, best of all, among their relatives. At the age of twelve the child is already a good musician. [...] My own daughter [...] loves it [to play/practice]. She sees that in a musical life there is such horrible competition, either it is worth doing [seriously], or not at all. She has already received her grandfather's instrument (quoted in Békési 2003, 65).

\section{[ [...] ha fölülröl fogja meg a vonót, ahogy kell ... akkor érzéke van hozzá. Ha meg cask megmarkolja, mint egy botot, akkor nem lesz belöle jó zenész. A szülök évszázadok óta rengeteg idöt és energiát forditanak arra, hogy figyeljék, miben tehetséges a gyerek. Hároméves korától az apja tanítgatja, próbálgatja vele a különbözö hangszereket. Aztán, ha kiderül, hogy a gyereknek mihez van kedve, keresnek hat-hét éves korban egy jó tanárt az ismeretségi vagy föleg a rokonsági körböl. Tizenkét eves korban a gyerek már jó zenész. [...] Az én lányom [...] szereti csinálni. Látja, hogy a zenei életben olyan iszonyú versant van, hogy vagy így érdemes csinálni, vagy sehogy. Már megkapta a nagyapja hangszerét.]}

A younger musician (eighteen years of age and studying at a conservatory in 2001 or 2002) reported similarly intensive family investment in children's music education: his family had chosen his instrument based on him grasping the bow correctly when he was very small, and his grandfather, a restaurant primás ('violinist-bandleader'), taught him violin for an hour every morning in the period before he started preschool. Lessons grew to two hours when he was older. The family's goal was for him to develop into a violinist who could be part of a family band, since other family members already played the clarinet, cimbalom, and bass (interview quoted in Békési 2003, 66). Déki Lakatos had a similar experience in an earlier period, though his grandfather would not teach him until he had "built up his spine," around seven years of age. His grandfather, the Prague Conservatory-trained Floris Lakatos, treated his pedagogical wisdom as 
Hooker, Lynn M. "The Kodály and Rajkó Methods: Voices, Instruments, Ethnicity, and the Globalization of Hungarian Music Education in the Twentieth Century." Hungarian Cultural Studies. e-Journal of the American Hungarian Educators Association, Volume 6 (2013): http://ahea.pitt.edu DOI: 10.5195/ahea.2013.117

secrets of the family trade, closing windows and shutters to keep passers-by, even Roma friends, from discovering how he taught. When Déki Lakatos was about fifteen and had achieved a certain level of mastery, he embarked on his professional career when his father brought him into his restaurant band as a tanuló ['student'] second violinist (Interview with author, March 8, 2012). Such apprentice members of restaurant bands were usually not given regular pay, but they shared in the band's tips. One should note that this education process, unlike that in Kodály's method, is essentially instrumental rather than vocal, from the very beginning.

Though this long-standing, mostly informal training of Gypsy instrumentalists continued through the state-socialist era through today, socialist Hungary also developed an "official" school for training Gypsy musicians: the Rajkó Orchestra. This group was founded in 1952 as the Gypsy orchestra of the League of Working Youth [Dolgozó Ifjúság Szövetsége, abbreviated DISZ]. DISZ was dissolved in the aftermath of the 1956 Revolution and replaced by KISZ [Kommunista Ifjúsági Szövetség], the League of Young Communists; the Rajkó Ensemble continued as the Gypsy orchestra of the KISZ Központi Müvészegyüttes ['Central Artists' Ensemble'], one of thirty-four ensembles operating under this administrative umbrella (Diósi 1988, 92-93).

The name Rajkó, from the Romani word for "boy," belonged in the interwar period to an ensemble of Gypsy boys who played at the Ostende Café, a luxurious spot in Budapest's Erzsébetváros. One of the young members of that band, Gyula Farkas (1921-1990), became a karmester — usually translated "conductor" — but though a karmester might occasionally conduct in rehearsal, traditionally such bands worked without a conductor in performance. The primary role of a Gypsy band's karmester was as composer and arranger. Farkas worked at other restaurants as a young man both as musician and arranger, but beginning in 1951 he also began to write and arrange for the Hungarian State Folk Ensemble. From there he was recruited as the first artistic director of the newly formed state-socialist Rajkó Orchestra. Whereas the interwar Rajkó Orchestra was a novelty act whose members were able to earn money by taking requests at table and passing the plate, the postwar Rajkó was a stage ensemble whose aim, similar to that of other Hungarian stage folk ensembles of the era, was to raise Gypsy music up from the level of pub entertainment and make it suitable for the stage, in Hungary and abroad. Passing the plate was forbidden for Rajkó members. In Farkas' words:

The Pioneer Association called my attention to the fact that there are an extraordinary number of talented Gypsy children, no one is teaching them and they still fiddle [hegedülnek]. And this is the only way to bring the Gypsies into school, because the Gypsy child did not go to school, no matter that there was compulsory education. Then I was stunned: how could I do this now all at once. I quickly told acquaintances who had children of six-eight-ten years of age, and they could already play. First the parents laughed: we don't even have bread, much less [nemhogy] a Rajkó Orchestra. Still, it became serious (Diósi 1988, 9495).

[Az úttöröszövetség hívta fel a figyelmet, hogy rendkívül sok tehetséges cigány gyerek van, nem tanítja öket senki se, és mégis hegedülnek. És a cigányokat cask így lehet befogni az iskolába, mert a cigány gyerek nem ment el az iskolába, hiába volt az iskolakötelezettség. Akkor nagyon megdöbbentett engem: hogy csináljam ezt én most hirtelen. Hát gyorsan szóltam az ismerösöknek, akiknek volt hat- 
Hooker, Lynn M. “The Kodály and Rajkó Methods: Voices, Instruments, Ethnicity, and the Globalization of Hungarian Music Education in the Twentieth Century." Hungarian Cultural Studies. e-Journal of the American Hungarian Educators Association, Volume 6 (2013): http://ahea.pitt.edu DOI: 10.5195/ahea.2013.117

nyolc-tíz eves gyerekük, és már valamennyire tudtak muzsikálni. Elöször kinevettek a szülök: még kenyerünk sincs, nemhogy rajkózenekar. Mégis komoly lett.]

After an initial audition and rehearsal period, the new ensemble began performing. They had their first major international success at the 1957 World Youth Festival in Moscow, the largest such congress, an event that attracted around 34,000 young people from 131 countries (Koivunen 2009, 49). The Rajkó won a silver medal in their division of the festival's cultural competition. Though other Hungarian artists won gold medals, the Rajkó Orchestra was recognized as an audience favorite, one possible factor in the decision of Magyar Ifjúság ['Hungarian Youth'], the KISZ newspaper, to feature a photo of one of Rajkó's young soloists on its front page instead of one of the gold medalists in a report from the festival ("Tíz arany, öt ezüst" 1957, 1). After this success the ensemble began to tour more and more. Between 1958 and 1962, they went on five tours to East Germany alone, giving 122 performances there, in towns both large and small, for audiences ranging from peasants to upper-level government officials (“122" 1962, 5). By the 1980s they had performed in over a hundred countries in addition to their many domestic performances.

Rajkó was not unusual among Hungary's other stage folk ensembles of the era in performing frequently both at home and abroad, but unlike those other ensembles, Rajkó was more than a performing group: it was also an all-encompassing educational institution. Members were provided a stipend and schooling; around twenty stayed in the dormitory, while the rest stayed at home or with relatives. Again in Farkas' words, the students "do not even need to buy a pencil-the state, KISZ, provides everything" [még egy ceruzát se kell venni, mindent az állam ad, a KISZ] (Diósi 1988, 94). A newsreel dedicated to the ensemble and its attached school celebrated the Rajkó system as an example of the state's dedication to developing talented minority youth (Fehéri 1967).

The center of the education provided by the Rajkó school was, of course, music. Students studied the general curriculum and prepared for the érettségi ('school-leaving') exam, without which they could not pursue a performing license, required for anyone seeking to make a living as a performer. But non-musical subjects were a distant second to music, both in and out of the classroom. Music studies for Rajkó members included not only individual study on their instruments but also "kottaóra" ['score class'] and, of course, orchestra rehearsals. Rajkó members, like most Gypsy musicians in the second half of the twentieth century, were thoroughly musically literate. Many students had attended music primary schools and had thorough preparation in solfège in this way, and they generally studied their individual instrumental repertoire from printed music. In the orchestra, however, only the conductor, Gyula Farkas, had a score, and he used it mainly for reference; he showed the players their parts from memory.

While those parts of the musical curriculum that used printed music were taken seriously, the heart of the program was the orchestra, in part because of this teaching approach. In the words of András Suki Sr. (b. 1955), who was a member of the Rajkó Orchestra from age ten to twenty-seven and since 2006 has himself been artistic director of the Rajkó Orchestra, "The étude that was asked of us up there [in the teaching studio] only lived while we were up in class. What we learned from Uncle Gyula, we knew by heart" [Az az etüd, amit ott fönt kértek tölünk, csak addig élt amíg font voltunk a órán. Amit Gyula bácsival tanultunk, fejböl tudtuk] (Diósi 1988, 98). Farkas would show the students the appropriate fingerings, hand positions, and 
Hooker, Lynn M. “The Kodály and Rajkó Methods: Voices, Instruments, Ethnicity, and the Globalization of Hungarian Music Education in the Twentieth Century." Hungarian Cultural Studies. e-Journal of the American Hungarian Educators Association, Volume 6 (2013): http://ahea.pitt.edu DOI: 10.5195/ahea.2013.117

bowing, and then have the orchestra repeat the material until they had mastered it (2012 interview with Edit Németh).

One might compare such a teaching approach to the Suzuki method, which originated in Japan and spread to the United States and elsewhere. Like the Rajkó method, the Suzuki method is predominantly about teaching the violin and includes a strong emphasis on aural/oral learning over reliance on printed music. According to one present-day American Suzuki teacher, a number of Western Suzuki teachers formerly took this emphasis to an extreme: "The children weren't allowed to look at a piece of music — it was evil to look at music!" (Niles 2012, 40). More recently, however, Suzuki teaching develops music literacy earlier than in the past. Though music literacy has always been assumed for Rajkó members since its post-war (re-)foundation, literacy has never looked important for Gypsy orchestras, including the Rajkó. Whereas western orchestral players are expected to perform from printed music, Gypsy orchestra members have almost never done so, at least not in public; their music literacy is concealed. Successful Gypsy musicians need both a large memorized core repertoire and strong memorization skills. Moreover, playing from memory can encourage players to listen more closely to each other and may allow freer improvisation. Gyula Farkas' aurally based teaching approach developed all of those aspects of the students' musicianship.

Though the aural emphasis in the Rajkó teaching approach immediately suggests a parallel to the Suzuki method to this American, however, among former Rajkó members it is Kodály’s pedagogical approach that is more salient, not surprising given Kodály’s continuing dominance in Hungarian music education. Several former members in interviews with me called Farkas' pedagogical approach the "Rajkó method," implicitly referencing the Kodály method. There is little fundamental similarity between the Kodály method and the Rajkó method: whereas the explicit aim of the Kodály method is the development of music literacy, the Rajkó method is about developing aural skills and playing skills mainly away from the printed page; whereas the Kodály method is organized overwhelmingly around choral singing, the Rajkó method is about developing excellent instrumental playing, particularly in an ensemble setting. The comparison by Rajkó members past and present to the Kodály method is apparently about the perceived prestige of Kodály, compared to the perceived dismissal of the skills of Rajkó members outside of a shrinking circle of Roma musicians and non-Roma supporters and fans who follow it.

\section{Conclusion: Spreading Hungarian Music and Hungarian Music Education around the World}

The relative fame of the Kodály method and obscurity of the Rajkó method as methods of music pedagogy cannot, however, be put down to any such slight against Roma. In the twentiethand twenty-first-century context, music pedagogy methods are publicized in print, in teachertraining courses, and in pedagogy workshops. Both Kodály's and Suzuki's methods proliferated globally in these ways. Gyula Farkas' ensemble also traveled around the world, of course, but not as an example of his pedagogical methods; rather they were performers first and last.

Although the children's proficiency can easily be ascribed to their rigorous instruction and practicing and to their immersion in music practically from the cradle, both Roma and nonRoma may overlook these factors and instead subscribe to the more Romantic idea that these youngsters" musical talent is "in their blood" — not due to hard work or any particular teaching practice. Gypsy bands' tradition of performing without printed music further plays into the idea that the musicians are playing directly from the "soul," without requiring intellectual 
Hooker, Lynn M. "The Kodály and Rajkó Methods: Voices, Instruments, Ethnicity, and the Globalization of Hungarian Music Education in the Twentieth Century." Hungarian Cultural Studies. e-Journal of the American Hungarian Educators Association, Volume 6 (2013): http://ahea.pitt.edu DOI: 10.5195/ahea.2013.117

engagement. Audiences hearing the Rajkó Ensemble perform, whether at home or abroad, were and are unlikely to wonder what kind of excellent teaching methods brought them to such heights. Rather, the attraction of their performances was the spectacle: the colorful costumes of the musicians and dancers, the youth of the performers, plus an element of mystique lent by their Gypsiness, an expectation of "innate" musical talent (Gelbart 2010, 86).

In the post-socialist era the Rajkó Ensemble has struggled financially. State support for the group disappeared in the transition to democracy, leaving its leadership to seek operating funds from tourist performances and philanthropic organizations. The legitimacy of the repertoire it taught was questioned not only by followers of Kodály-among whom many educated Hungarians counted themselves at least to some degree - but also by Roma activists and musicians who promoted Roma folklor ['folklore'] ensemble music, especially that in the Romani language rather than Hungarian, as a more authentic representation of Roma culture (see Lange 1997, 8, 16-18). Also, the employment sector for which the Rajkó Ensemble prepared its young members, the restaurant music industry, continued to shrink in a changing cultural and economic climate. Though some young people from musician Gypsy families still pursue musical training, they often look to other genres, whether jazz or classical music, for their futures; many musician parents steer their children away from music altogether.

The influence of the Kodály method in music education, meanwhile, continues to be strong both in Hungary and abroad. One aspect of it, however, has been challenged especially strongly: the axiom that music education, like language education, should be founded on a monocultural core. While in an earlier era many judged that bilingual language development among young children could lead to dangerous speech delays and educational problems, recent research has shown that "the vast majority of cognitive differences were advantageous to the bilingual children" (Bialystok 2001, 232). Kodály's urging toward thorough education in Hungarian language and music came out of a history in which they had sometimes been neglected in favor of education in German, the language of imperial power. But in a country like the United States with an immigrant-based history and a multiethnic citizenry, the issue of deciding what culture should dominate in schools is more charged. Kodály himself recognized that "it is a difficult question, what is American folk song?" (Houlahan \& Tacka 2008, 39) While teachers around the world have made use of the pedagogical techniques of the Kodály method, many American teachers find Kodály's elevation of folk music and his rejection of popular music "challenging" in the American context (Campbell \& Scott-Kassner 1995, 53). By contrast with the Hungarians' insistence on one pure cultural core for children's repertoire, American authors Patricia Shehan Campbell and Carol Scott-Kassner stress that

... as products of a multiethnic and multiracial society, children must be led to listen and to respond to the aesthetic components and cultural meanings of more than a single musical tradition. They are living in a less-homogenized world than any earlier generation, one that demands their understanding of many people. Ideally, through their musical experiences sensing its ebbs and flows, learning its logical structures, and feeling its power, children may come to understand not only the music, but also the music makers. They may learn to take not of not only the differences among people and their musical expressions, but also the similarities that transcend all people. (313) 
Hooker, Lynn M. “The Kodály and Rajkó Methods: Voices, Instruments, Ethnicity, and the Globalization of Hungarian Music Education in the Twentieth Century." Hungarian Cultural Studies. e-Journal of the American Hungarian Educators Association, Volume 6 (2013): http://ahea.pitt.edu DOI: 10.5195/ahea.2013.117

In today's world, the children of Hungary, like the children of the United States, live in a much less homogenized world than ever before. Moreover, although Hungary's national identity from the late eighteenth century onward has been formed (in part defensively) around the idea of a Magyar culture-nation, it, like the United States, has long been multi-ethnic; indeed, Hungary's founding king, St. István, reportedly wrote in his Exhortations to his son (c. $1015 \mathrm{CE}$ ) that "A nation consisting of a single language and a single culture is weak and fragile" (cited in Lendvai 2003,36 ). Teachers of music have a unique opportunity to celebrate the value of the country's ethnic diversity, particularly the contributions of the Roma musicians who made Hungary's music famous around the world.

\section{Works Cited}

“122.” 1962. Magyar Ifjúság 6, no. 2 (Jan. 13, 1962), 5.

Beckles Willson, Rachel. 2007. Ligeti, Kurtág, and Hungarian Music During the Cold War. Cambridge: Cambridge University Press.

Békési, Ágnes. 2003. Muzsikusok [Musicians]. Budapest: Pont Kiadó.

Berlász, Melinda and Tibor Tallián, eds. 1984. Iratok a magyar zeneoktatás történetéhez, 1945-1956 [Writings on the History of Hungarian Music Education]. Budapest: MTA Zenetudományi Intézet.

Bhattacharjee, Yudhijit. 2012. "Why Bilinguals Are Smarter." The New York Times (March 18, 2012). http://www.nytimes.com/2012/03/18/opinion/sunday/the-benefits-ofbilingualism.html

Bialystok, Ellen. 2001. Bilingualism in Development: Language, Literacy, and Cognition. Cambridge and New York: Cambridge University Press.

Bónis, Ferenc, ed. 1974. The Selected Writings of Zoltán Kodály, trans. Lili Halápy and Fred Macnicol. London: Boosey \& Hawkes.

Campbell, Patricia Shehan and Carol Scott-Kassner. 1995. Music in Childhood From Preschool through the Elementary Grades. New York: Schirmer Books.

Choksy, Lois. 1999. The Kodály Method I: Comprehensive Music Education. Upper Saddle River, NJ: Prentice Hall.

Choksy, Lois, Robert M. Abramson, Avon E. Gillespie, David Woods, and Frank York. 2001. Teaching Music in the Twenty-First Century, $2^{\text {nd }}$ ed. Upper Saddle River, NJ: Prentice Hall.

Diósi, Ágnes. 1988. Cigányút [Gypsy Road]. Budapest: Szépirodalmi Könyvkiadó.

Eősze, László, Micheál Houlahan, and Philip Tacka. "Kodály, Zoltán. Grove Music Online. Oxford Music Online. Oxford University Press. http://www.oxfordmusiconline.com/subscriber/article/grove/music/15246. Accessed July 10, 2013.

Fehéri, Tamás. "Rajkók.” H, 1967. MaNDA (Magyar Nemzeti Digitális Archívum) NJF 1399. Film. Excerpt at http://www.youtube.com/watch?v=_qpKNObpRoQ . Accessed August 8, 2013.

Friss, Gábor. 1969. “The Music Primary School.” Musical Education in Hungary, ed. Frigyes Sándor. Budapest: Corvina. 133-172.

Gelbart, Petra. 2010. Learning Music, Race and Nation in the Czech Republic. Ph.D. diss.: Harvard University. 
Hooker, Lynn M. "The Kodály and Rajkó Methods: Voices, Instruments, Ethnicity, and the Globalization of Hungarian Music Education in the Twentieth Century." Hungarian Cultural Studies. e-Journal of the American Hungarian Educators Association, Volume 6 (2013): http://ahea.pitt.edu DOI: 10.5195/ahea.2013.117

Haraszti, Miklós. 1988. The Velvet Prison: Artists under State Socialism. London: I. B. Tauris \& Co.

Houlahan, Micheál and Philip Tacka. 2008. Kodály Today: A Cognitive Approach to Elementary Music Education. New York: Oxford University Press.

International Kodály Society. "About the IKS.” http://www.iks.hu/General/about-the iks.html. Accessed July 16, 2013.

Irsai, Vera, Magda Szávai, and Lili Veszprémi. 1969. "Primary Music Instruction,” in Musical Education in Hungary, ed. Frigyes Sándor. Budapest: Corvina. 173-206.

Járdányi, Pál. 1969. "Folk-Music and Musical Education.” Musical Education in Hungary, ed. Frigyes Sándor. Budapest: Corvina. 11-24.Kemény, István and Béla Janky.

2005. "Roma Population of Hungary 1971-2003." Roma of Hungary, ed. István Kemény. Boulder, CO: Social Science Monographs. 70-225.

Kodály, Zoltán. 2007. Visszatekintés: összegyïjtött írások, beszédek, nyilatkozatok [Looking back: Collected writings, speeches, declarations], $2^{\text {nd }}$ ed., ed. Ferenc Bónis, 3 vols. Budapest: Argumentum.

Koivunen, Pia. 2009. "The 1957 Moscow Youth Festival: Propagating a new, peaceful image of the Soviet Union." In Soviet State and Society Under Nikita Kruschev, ed. Melanie Ilic and Jeremy Smith. New York: Routledge. 46-65.

Lange, Barbara Rose. 1997. "Hungarian Rom (Gypsy) Political Activism and the Development of Folklór Ensemble Music." The World of Music 39.3 (1997): 5-30. Print.

Lendvai, Paul. 2003. The Hungarians: A Thousand Years of Victory in Defeat, trans. Ann Major. Princeton, NJ: Princeton University Press.

Makki, Marie-Rose. 2012. “Interjú Snétberger Ferenc világhírü gitárvirtuózzal: Nyomortelepek kincsei" [Interview with world-famous guitar virtuoso Ferenc Snétberger: Treasures from poor settlements]. Hetek [Weeks] 16.12 (March 23, 2012) http://www.hetek.hu/interju/201203/interju_snetberger_ferenc_vilaghiru_gitarvirtuozzal. Accessed July 30, 2013.

Messing, Vera, Violetta Zentai, and Júlia Szalai. 2010. Interactions between the ethnic composition in school and students' performance, self-esteem and future aspirations. EDUMIGROM Policy Brief no. 3. http://www.edumigrom.eu/sites/default/files/field_attachment/page/node5385/edumigrompolicybrief3june2010.pdf

Niles, Laurie. 2012. "The Method and the Movement: The Spread of Suzuki." The Strad (September 2012): 34-40.

Pukánszky, Béla. 2005. "Kodály Zoltán zenepedagógiája és az életreform” [Zoltán Kodály's music pedagogy and life-reform]. Iskolakultúra [School Culture] (Feb. 2005): 26-35. http://www.iskolakultura.hu/ikultura-folyoirat/documents/2005/2/tan2005-2.pdf. Accessed August 9, 2013.

Sándor, Frigyes, ed. 1969. Musical Education in Hungary. Budapest: Corvina.

Tini, Chris. 2007. “Örökzöldek: A Rajkó Zenekar" [Evergreens: The Rajkó Orchestra], Amaro Drom: Roma lap (November 2007). http://www.amarodrom.hu. Accessed August 7, 2013.

Szellemi Kulturális Örökség. "Rajkó módszer-jó gyakorlat" [Rajkó method-good practice]. Drawn from "Beszélgetés Farkas Gyulával, 1986" [Conversation with Gyula Farkas, 1986]. http://www.youtube.com/watch?v=q7OzSxb5JDk. Accessed August 7, 2013. 
Hooker, Lynn M. “The Kodály and Rajkó Methods: Voices, Instruments, Ethnicity, and the Globalization of Hungarian Music Education in the Twentieth Century." Hungarian Cultural Studies. e-Journal of the American Hungarian Educators Association, Volume 6 (2013): http://ahea.pitt.edu DOI: 10.5195/ahea.2013.117

“Tíz arany, öt ezüst, tízenhat bronz érmet nyert kulturális küldöttségünk a VIT-en" [Our cultural delegation has won 10 gold, 5 silver, and 16 bronze medals at the World Youth Festival]. 1957. Magyar Ifjúság [Hungarian Youth] 1.34 (August 10, 1957). 1. 